\title{
Why IAU?
}

\author{
Remus Pricopie
}

\section{How Can We Assess the Value of 70 Years of Work?}

We all know that evaluation is a sophisticated science. However, when we talk about celebrating 70 years of the International Association of Universities (IAU), the word "sophisticated" gets an even deeper meaning. How do we evaluate the activity of a global organization, founded in 1950 by UNESCO (IAU, 1950), whose mission it is to be the voice of universities worldwide and the main defender of the two fundamental academic values: (i) academic freedom and (ii) university autonomy? Naturally, an anniversary is always an occasion to look back, just as it is natural to look ahead. But what do we look for when we scan the seven decades of IAU activity? Where do we start? What do we quantify? What lessons do we learn from our experiences so far and what do we decide to adjust for the years to come?

Precisely because the questions are not simple at all and the answers can have several "correct" versions at the same time, the IAU Board, chaired by Professor Pam Fredman, encouraged and fully supported the efforts of the IAU Secretariat, led by Dr. Hilligje van't Land, to build a multi-level framework in which each member of the global academic community, anyone who has known, interacted, worked for or benefited from this organization, can express themselves in a specific way. One of these 'levels' is this book, to which, to a small extent, the university I represent, the National University of Political Studies and Public Administration (SNSPA), has also contributed.

Since we are talking about specific answers, I will try to give some as well. Obviously, they have to do with my educational profile, my professional experiences and my interactions with IAU. At the same time, I am convinced that these can be similarly found in other parts of the world, or at different moments in the existence of IAU. The matrix that I will use in "my evaluation" is a very simple one. I will initially

\footnotetext{
R. Pricopie $(\bowtie)$

National University of Political Studies and Public Administration, Bucharest, Romania

e-mail: remus.pricopie@snspa.ro 
refer to three distinct layers: individual, institutional, system-wide. The individual can be anyone who, during the 70 years, benefited, was assisted or guided by the IAU, directly or indirectly, through the results of its work. The institution, in this case, is the university, even though other types of higher education institutions also come into play. At the systems' level, although we can look at many things, it is the global conceptual system relating to the "idea of the university". If we wanted, we could also consider the university system in a certain region or country. Each of these levels will be analyzed not in a holistic way - here is not the place or time - but from a personal perspective. However, I do believe that this kind of approach will reveal and emphasize the need for IAU and its value. To this I will add a disruptive factor: stress or crisis. In the opinion of many specialists, an organization cannot be classified as "solid" unless it can prove that it can survive difficult times, without altering its mission.

\section{From the Golden Book to the Golden Portal}

I am twenty years younger than IAU. I was born in 1970 and grew up in a relatively isolated village, somewhere in rural Romania. Although the rural area has always been a place where education found itself in a precarious state, I was somewhat privileged by the fact that I was under the intellectual influence of several teachers, priests and engineers in my extended family. Also, I had the advantage that I was close to the largest university center, Bucharest. I therefore always had the option of pursuing a degree in higher education, which is what happened. The revolution of 1989, which led to the abolition of the communist regime in Romania, found me a student at the University of Bucharest, in the teacher training program.

The new democratic society to emerge did not settle down easily and the word "confusion" was best characterizing these times. In this general state of confusion and hesitation, education guided me quite easily to what I was going to achieve in my career. While attending postgraduate courses at my current university (SNSPA) and researching for a paper, I discovered in the library of the Ministry of Education the "Golden Book": International Handbook of Universities (IHU). No, the IHU wasn't actually clad in gold, but for me it was like a treasure. In this pre-Internet world, that huge book (over 1.000 pages), quite old, served as a window to the fascinating world of universities around the globe (IAU, 2020). I leafed through all of them, page by page, country by country, university by university and it instilled in me the idea to study in a foreign country. Since then, I have studied in nine universities, in five countries and I have collaborated on an institutional level with more than 2.000 universities from around the world, all of which are obviously listed on those IHU pages.

"The Golden Book", which I discovered at the age of 26, had a major impact on me. Since encountering that "map of academic maps", my life and that of my family has changed. It is difficult for us to know just how many other young people in the world were similarly touched by "The Golden Book" during their educational journey. But what we do know for sure is that what the IAU has managed to do in all 
these years: to build the most sophisticated register of higher education institutions in the world, while being in permanent dialogue with the governments of 196 countries and territories. It is not only young people like me searching for an academic path who have benefitted from these huge efforts. All those who have studied abroad in these 70 years (UNESCO and World Bank statistics will indicate tens of millions of international students in this time interval), relied on this global catalog of academic programs to get their credentials accredited and officially recognized by the national authorities.

Today, as mentioned by the editors Hilligje van't Land, Andreas Corcoran and Diana Iancu in the Introduction, "The Golden Book" has become "The Golden Portal", as in that the information has shifted to a global portal, known as the World Higher Education Database (WHED). This means that through a simple click, anyone can explore the vast global academic world, including 20,000 higher education institutions and listing probably well over 1.000.000 undergraduate, graduate and Ph.D. programs. Imagine how many academic paths this "Golden Portal" has shaped and continues to shape, year after year, for millions of young people around the world. Young people, who are driven by a thirst for knowledge. Just imagine how many lives and destinies have been shaped by this huge academic map of the world.

This alone - the creating and updating of the "The Golden Book" - would have been enough to justify its 70 years of existence. But the work of IAU has been far more than that.

\section{A Global Community of Universities}

IAU is a global community of universities, one that seeks to ensure and support "the engines" of the intellectual life in the world. And the logic of all actions carried out under the auspices of the IAU is that every university in this world should have the opportunity to dialogue with other universities, similar or different, to find solutions to the challenges they face. The circumstances and problems universities face are in many respects different, especially when we cross continents and cultural borders. It would be difficult, for example, for a Romanian university to implement American higher educational financial policies, just as, in the same way, a US university would not be in a position to understand how someone in Romania could study medicine in a high-quality program for only $10.000 \$$ a year. But dialogue and the patience to understand other paradigms is the path to progress.

As a young rector of SNSPA, I immediately ventured to engage in IAU events and meetings. True, I had known IAU long before I became rector. I knew what it offered from my previous experiences working on governmental public policy. In my new capacity however, I believed it fundamental to build opportunities for my university, for my colleagues and students for a global dialogue. Since 2012, many of the members of the SNSPA academic community (academics, technical staff, and students) have participated in events, conferences, training programs, site visits on all continents and within different frameworks built under the umbrella of IAU. 
All this, in connection with other European or global projects, has given SNSPA today one of the strongest international profiles among Romanian universities. This "profile" can be depicted as: programs in foreign languages, partnership with foreign universities, the highest rate of research projects per professor in Romania, the first Romanian university participating in the consortium - CIVICA - that won a grant within the new European Universities Initiative (CIVICA, 2021), one of the highest rates of academic mobility within Eastern Europe, a leader in digital education, a strong voice for academic freedom and a fighter against any political and ideological interference in academic life, one of the very active universities heavily involved in research for policy design etc.

Obviously, these are the words of a rector who, after eight years in office, can look back and evaluate what his university has achieved with the support of his university colleagues and colleagues from the IAU. But these are the kind of achievements that not just SNSPA, as a member of IAU, has benefited from over the years. All Members can engage in the opportunities IAU offers and do so according to their needs and academic goals. Therefore, in addition to the short story of SNSPA, we could undoubtedly mention thousands of other success stories as well, stories that show how perhaps millions of students and the communities and countries in which they live have benefited from being Members of IAU.

\section{The Shape of the Future}

There is an area in which IAU has worked from the beginning but that specific area is one that is not always easily grasped: the shaping of the future of universities and, in a way, that of our societies.

The university is often said to be one of the few organizations that have survived a millennium. It is true, in a way. But it is also true that the university, as a millennial institution, has shown that it is sensitive to the new, that it has the ability to understand social, political, economic trends, that it has the courage to question the rules of the present in order to make room for new rules and that, not least, it has the ability to modernize, to change from within, and not under the pressure from external factors. If we follow the history of universities and try to understand how these sanctuaries of knowledge survived, the answer is probably simple: because the university has always worked with the future, and sometimes even built and shaped this future.

IAU has worked and continues to work with the future, too.

At its inception, IAU worked within a framework that knew hardly any university cooperation outside national borders at all. It was a matter of vision to encourage universities to be free, independent, not to scare under the power of national governments and to do what they know best - education and research - in a collaborative way. Its inception in 1950 laid the foundations, on the one hand, for what we now call international higher education and, on the other hand, empowered universities to conceptually confront their own governments, when the case. 
In the early years of its establishment, IAU has repeatedly addressed the issue of the relationship between universities and authorities, how universities and their academic programs can be recognized across national borders, the issue of academic status and its freedoms. Massification, quality, mobility and internationalization were other topics discussed by IAU and its Member universities long before these phenomena took shape. The world had been warned in advance: the need for higher education is going to increase significantly, therefore, one better be prepared.

And this is how academic issues, once considered as $100 \%$ strictly national topics, have reached the agenda of international discussions, in various forms. UNESCO established a higher education division in the 70s, and two important institutes specialized in higher education - Romania - CEPES, 1972, and Venezuela-CRESALC, 1974 - were called into life. In addition, UN and UNESCO, inspired by the work of IAU, established a unique kind of institution (the United Nation University,1975) in Tokyo; the World Bank started to approach higher education as one of the important development actors; Europe launched the Erasmus mobility program and later, during the 90s, the Bologna Process, which became one of the most dynamic regional higher education movements in the world.

So, less than 25 years after the founding of the IAU, higher education officially became an "international theme", and the university the main actor in this theme. In the 90s, with the fall of the Iron Curtain, UNESCO, under Federico Mayor as Director-General, surrounded by one of the best teams of experts globally, enhanced the higher education agenda by organizing the first ever global higher education conference (UNESCO, 1998).

Eva Egron-Polak, in her contribution to this book, recounts how IAU was invited to contribute to the organization of the first UNESCO World Conference on Higher Education (WCHE), held in 1998. I cannot report on this "first hand" as I was not involved in this first edition, but I can comment it, however, on the second UNESCO WHEC, which took place in 2009. As I was personally involved in the organization of this event on behalf of the Romanian Government, I can say that IAU continued to be one of the most active actors, especially during the drafting of the final documents (UNESCO, 2009). As mentioned in this book by Stefania Giannini, Assistant Director-General on Education, UNESCO considers IAU to be one of the most important, if not the first collaborator on higher education when it comes to shedding light on the perspective of universities, including the organization of the third UNESCO WHEC, which will take place in 2022, in Spain.

But the IAU was not only present at the debates under the UNESCO umbrella. The Bologna Process, the collaboration of EU - Asia or EU - Latin America, the Francophonie, and many other projects, initiatives, and movements have had IAU as one of the key partners. IAU has participated in all major discussions that have taken place globally and that have led to the shaping of both the future of universities and of the societies in which we live.

Sometimes, a "world conference" is an event too far from the needs of many universities and communities, small and also large. Or, simply saying, some educational institutions prefer a local/regional perspective to a global one. That is why the IAU has not limited itself to the big global picture of social transformations and the role of 
the university as a globally recognized institution. In many cases, based on different governmental invitations, IAU assisted in defining and implementing various public policies. I repeat, there are many examples of such contributions. But, as I underlined in the first section of this paper, it is normal to mention the one I know best. In 2014, at the invitation of UEFIS-CDI, the Romanian institution specialized on research in public policy, worked with IAU on the internationalization of higher education, on two different levels: (1) to help the Romanian Ministry of Education to design the first ever Higher Education internationalization strategy; (2) to guide 20 universities in the shaping of their own vision and to prepare the appropriate university strategies on internationalization (UEFIS-CDI, 2014).

All these examples are, again, indisputable attributes of IAU's role and capacity. They show us not only the strength to understand the most important lines of force, globally, with regard to the need for knowledge and change; it also shows the dedication of the IAU team to work with almost every member, in a customized way, depending on the specificities of each.

\section{Celebrating ... in Pandemic Times}

It is clear that COVID 19 has become a black page in human history, with millions of lives lost and tens of millions more suffering as a result of this global crisis, including job losses, deteriorating living conditions, alarming increase in the level of insecurity, etc.

However, this moment of major crisis must also be seen as a test - harsh and unfortunate. It has shown us that IAU can act and serve the global academic community even during what by some has been described as "a time of war".

Perhaps our assessment of the IAU, whether holistic or a more personal, could not be complete without showing that the IAU is indeed an organization capable of dealing with complex situations and uncertainty. And how can an organization be better tested than in times of crisis.

We all, as member universities of a global community, have seen how the IAU has reacted immediately, transferring its entire activity online and continuing to provide strong support to its Members. Obviously, this would not have been possible without a motivated community and strong leadership (both at the Board and at the Secretariat level). The crisis has somehow given value not only to the work of 70 years of strong higher education cooperation, it also gives us the certainty that this organization, considered and recognized as "the global voice of higher education", is ready for the decades to come.

I do hope that we will meet to celebrate IAU's achievements while also planning ahead during the 16th IAU General Conference, October 25-28 2022, at UCD, in Dublin, Ireland. 


\section{References}

CIVICA - The European University of Social Sciences (2021). About CIVICA. Retrieved from: www.civica.eu/who-we-are/about-civica/

International Association of Universities (IAU) (1950). Constitution of the International Association of Universities. Retrieved from: https://iau-aiu.net/IMG/pdf/iau_constitution-en.pdf

International Association of Universities (IAU) (2020). International Handbook of Universities (IHU). Retrieved from: www.whed.net/Headline1.html

UEFIS-CDI (2014). Internationalizare, echitate şi management universitar pentru un învăţământ superior de calitate. Politici bazate pe evidente şi impactul asupra pieţei forţei de muncă. Retrieved from: iem http://iemu.forhe.ro/u(forhe.ro)

UNESCO (1998). World Declaration on Higher Education for the Twenty-First Century: Vision and Action. World Conference on Higher Education. Retrieved from: http://unesco_ world_declaration_on_higher_education_for_the_twenty_first_century_vision_and_action.pdf (bice.org)

UNESCO (2009). 2009 World Conference on Higher Education: The New Dynamics of Higher Education and Research For Societal Change and Development. Retrieved from: www.inqaahe. org/sites/default/files/UNESCO\%20communique.pdf

Remus Pricopie has been Professor and Rector of the National University of Political Studies and Public Administration (SNSPA) in Bucharest since March 2012. He served in the Romanian Government as Minister of National Education and Research, from 2012 to 2014. He is President of the Board of the Romanian-US Fulbright Commission, Vice-President of the International Association of Universities (IAU) and President of the EU-Latin America and Caribbean Permanent Academic Forum.

Open Access This chapter is licensed under the terms of the Creative Commons Attribution 4.0 International License (http://creativecommons.org/licenses/by/4.0/), which permits use, sharing, adaptation, distribution and reproduction in any medium or format, as long as you give appropriate credit to the original author(s) and the source, provide a link to the Creative Commons license and indicate if changes were made.

The images or other third party material in this chapter are included in the chapter's Creative Commons license, unless indicated otherwise in a credit line to the material. If material is not included in the chapter's Creative Commons license and your intended use is not permitted by statutory regulation or exceeds the permitted use, you will need to obtain permission directly from the copyright holder.

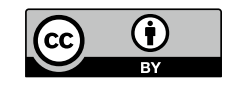

